\title{
Genetic and phenotypic differentiation of lumpfish (Cyclopterus lumpus) across the North Atlantic: implications for conservation and aquaculture
}

\author{
Benjamin Alexander Whittaker ${ }^{1}$, Sofia Consuegra ${ }^{1}$, Carlos Garcia de Leaniz ${ }^{\text {Corresp. } 1}$ \\ 1 Department of Biosciences, Centre for Sustainable Aquatic Research, Swansea University, Swansea, Wales, United Kingdom \\ Corresponding Author: Carlos Garcia de Leaniz \\ Email address: c.garciadeleaniz@swansea.ac.uk
}

Demand for lumpfish (Cyclopterus lumpus) has increased exponentially over the last decade, both for their roe, which is used as a caviar substitute, and increasingly also as cleaner fish to control sea lice in salmon farming. The species is classified as Near Threatened by the IUCN and there are growing concerns that over-exploitation of wild stocks and translocation of hatchery-reared lumpfish may compromise the genetic diversity of native populations. We carried a comparative analysis of genetic and phenotypic variation across the species' range to estimate the level of genetic and phenotypic differentiation and determined patterns of gene flow at spatial scales relevant to management. We found five genetically distinct groups located in the West Atlantic (USA, and Canada), Mid Atlantic (Iceland), East Atlantic (Faroe Islands, Ireland, Scotland, Norway, and Denmark), English Channel (England) and Baltic Sea (Sweden). Significant phenotypic differences were also found, with Baltic lumpfish growing more slowly, attaining a higher condition factor and maturing at a smaller size than North Atlantic lumpfish. Estimates of effective population size were consistently low across the NE Atlantic (Iceland, Faroe Islands, Norway), the area where most wild lumpfish are fished for their roe, and also for the aquaculture industry. Our study suggests that some lumpfish populations are very small and have low genetic diversity, which makes them particularly vulnerable to over-exploitation and genetic introgression. To protect them we advocate curtailing fishing effort, closing the breeding cycle of the species in captivity to reduce dependence on wild stocks, restricting the translocation of genetically distinct populations, and limiting the risk of farm escapes. 
1 Genetic and phenotypic differentiation of lumpfish (Cyclopterus lumpus)

2

3

4

5

6

7

8

9

10

11

12

13

14

15 across the North Atlantic: implications for conservation and aquaculture

Benjamin Alexander Whittaker, Sofia Consuegra, Carlos Garcia de Leaniz*

Department of Biosciences

Centre for Sustainable Aquatic Research

Swansea University, Swansea, Wales, United Kingdom

Corresponding author: c.garciadeleaniz@swansea.ac.uk 


\begin{abstract}
Demand for lumpfish (Cyclopterus lumpus) has increased exponentially over the last decade, both for their roe, which is used as a caviar substitute, and increasingly also as cleaner fish to control sea lice in salmon farming. The species is classified as Near Threatened by the IUCN and there are growing concerns that over-exploitation of wild stocks and translocation of hatchery-reared lumpfish may compromise the genetic diversity of native populations. We carried a comparative analysis of genetic and phenotypic variation across the species' range to estimate the level of genetic and phenotypic differentiation and determined patterns of gene flow at spatial scales relevant to management. We found five genetically distinct groups located in the West Atlantic (USA, and Canada), Mid Atlantic (Iceland), East Atlantic (Faroe Islands, Ireland, Scotland, Norway, and Denmark), English Channel (England) and Baltic Sea (Sweden). Significant phenotypic differences were also found, with Baltic lumpfish growing more slowly, attaining a higher condition factor and maturing at a smaller size than North Atlantic lumpfish. Estimates of effective population size were consistently low across the NE Atlantic (Iceland, Faroe Islands, Norway), the area where most wild lumpfish are fished for their roe, and also for the aquaculture industry. Our study suggests that some lumpfish populations are very small and have low genetic diversity, which makes them particularly vulnerable to over-exploitation and genetic introgression. To protect them we advocate curtailing fishing effort, closing the breeding cycle of the species in captivity to reduce dependence on wild stocks, restricting the translocation of genetically distinct populations, and limiting the risk of farm escapes.
\end{abstract}




\section{INTRODUCTION}

The control of parasitic sea-lice (Lepeophtheirus salmonis) is one of the most pressing problems facing salmon farming (Torrissen et al. 2013; Treasurer 2002), as sea-lice have become resistant to chemical treatment (Aaen et al., 2015; Lees et al., 2008) and threaten the sustainability of the industry. Several species of cleaner fish have been used as an alternative to the use of antiparasitic therapeutants (Treasurer 2018), but the lumpfish (Cyclopterus lumpus) is proving the most useful as, in contrast to other cleaner fish like wrasse, it continues to feed on sea lice at low temperatures and is easier to rear in captivity (Imsland et al., 2014; Powell et al., 2018a). Demand for lumpfish has increased exponentially since 2012 (Powell et al., 2018a; Treasurer, 2018). However, nearly all lumpfish used in salmon farming are still derived from wild broodstock (Jonassen et al., 2018a), and as they are generally used in a single salmon production cycle (Powell et al., 2018a), satisfying aquaculture demands can put considerable pressure on wild stocks.

Lumpfish has been classified as Near Threatened in the IUCN Red List (Lorance et al. 2015), but information on the conservation status of different populations is very limited, and it is likely that some populations are already overexploited (Myers \& Sjare, 1995; Powell et al., 2018a). Ripe females have traditionally been targeted for their roe, which is processed and sold as a cheap alternative to caviar, and while the Icelandic and Greenland lumpfish fisheries are closely monitored, others are largely unregulated (Powell et al., 2018a; Kousoulaki et al., 2018). A strong reduction in catch per unit effort has been detected in some lumpfish fisheries over the last 25 years (Lorance et al., 2015), and there are concerns that removing additional spawners for the expanding lumpfish aquaculture industry could impact on some small populations (Hedeholm et al., 2014; Powell et al. 2018a,b), as it has been reported for other cleaner fish fisheries (Halvorsen et al., 2017).

Stock movements represent an additional risk to wild lumpfish as large numbers of hatcheryreared lumpfish are being translocated across the North Atlantic to supply salmon farms (Jonassen et al., 2018b; Treasurer et al., 2018) and this could pose a potential threat to local populations. For example, over 85\% of all lumpfish deployed in Scotland during 2017 originated from eggs imported from Iceland and Norway, and none came from local sources (Treasurer et al., 2018). In Ireland, 70\% of lumpfish deployed during 2015-2016 were derived from eggs imported from Iceland and Norway (Bolton-Warberg et al., 2018), while in the Faroe Islands nearly all lumpfish used during 2014-2016 were of Icelandic origin (Steinarsson and Arnason, 2018; Johanssen et al., 2018). There is a danger that if non-native lumpfish escape from salmon farms they could interbreed with local populations and result in genetic introgression (Powell et al., 2018a), as has been reported for farmed salmonids (e.g. Consuegra et al., 2011). Lumpfish translocations are likely to intensify in the near future (Jónsdóttir et al., 2017), and while escapes of lumpfish have not yet been reported, these seem largely inevitable in open salmon net-pens, as have already been documented for two species of wrasse (Jansson et al., 2017; Faust et al., 2018). Whether escapes can have a genetic impact on local lumpfish populations will depend on the number of escapees, their reproductive success, and the extent of genetic differentiation between local and introduced fish, but none of these parameters are currently known. 
Lumpfish are distributed across a vast marine area, extending to both sides of the North Atlantic and into the Baltic (Davenport 1985; Powell et al., 2018b), and there is thus scope for substantial differentiation. Soon after hatching, the larvae attach to the substrate using a specialized suction cup, which probably limits larval dispersal (Davenport, 1985). Tagging studies suggest that, although adults can swim up to $49 \mathrm{~km} /$ day, some individuals remain within a restricted $80 \mathrm{~km}$ range after +250 days at liberty (Kennedy et al., 2015). There is also evidence of homing (Kennedy et al., 2014), which will favour reproductive isolation and may result in stock differentiation. For example, spawning time may vary by two months within single populations (Wittwer and Treasurer, 2018), but as much as seven months among populations, from January in the English Channel (Powell et al., 2018b) to August near the Arctic circle (Jónsdóttir et al., 2018). Population differences may also exist in growth and behaviour (Johannesen et al., 2018) and, as these are maintained under common rearing conditions (Imsland et al., 2016; BoltonWarberg et al., 2018), they are likely to be inherited. Such differences suggest that lumpfish may form discrete populations, and that these may be adapted to local conditions. Yet, the extent of genetic differentiation in lumpfish is uncertain. Thus, while significant genetic differences have been found at large spatial scales using microsatellite markers (i.e. Canada vs Norway; Pampoulie et al., 2014), populations at smaller scales appear to be relatively homogenous. For example, lumpfish sampled in the English Channel appear to be to largely undifferentiated (Consuegra et al., 2015), as do fish sampled along the Norwegian coast (Jónsdóttir et al., 2017). In contrast, in Greenland two genetically distinct groups have been found in the north and south (Garcia-Mayoral et al., 2016), suggesting that there can also be some fine scale genetic structuring.

\subsection{Aims}

There were three aims of this study. First, given their limited larval dispersal and evidence for homing, we hypothesised that lumpfish might display genetic isolation by distance, with populations closer together being more genetically similar than those further apart (Rousset 1997). By sampling across the whole range, we aimed to estimate the level of genetic and phenotypic differentiation, and determine the patterns of gene flow across the species' range, at spatial scales relevant to management. Secondly, we wanted to know to what extent lumpfish translocations could pose a potential genetic risk to local populations. For this, we examined if Icelandic and Norwegian lumpfish, the two most common sources of lumpfish in aquaculture, were genetically distinct from lumpfish populations present in other salmon farming areas (i.e. Ireland, Canada, Scotland, Faroe Islands) with whom they might interbreed. As lumpfish aquaculture is very recent, our estimates of genetic structure on wild lumpfish populations might serve as genetic baselines against which the impact of farm escapees might be gauged, as done for Atlantic salmon (Gilbey et al., 2017). Finally, as some lumpfish populations may be endangered, we provide estimates of effective population size, and test for the existence of genetic bottlenecks to better understand their conservation status.

\section{MATERIAL AND METHODS}

\subsection{Collection of samples}

Fin tissue was obtained from 410 lumpfish originating from 15 sites across the species' range (Table 1) and were stored in $96 \%$ ethanol at $-20^{\circ} \mathrm{C}$ until analysis. Sites located within an $80 \mathrm{~km}$ radius (the estimated maximum range of dispersal, Kennedy et al., 2015) were pooled together to 
132 minimise the risk of spatial pseudo-replication. Samples were pooled from the Faroe Islands 133 (Klasvík and Kollafjørður, c. 20km), Denmark (Køge Bay and Mosede Havn, c. 13km) and

134

135

136

137

138

139

140

141

142

143

144

145

146

147

148

149

150

151

152

153

154

155

156

157

158

159

160

161

162

163

164

165

166

167

168

169

170

171

172

173

174

175

176

177

Sweden (survey hauls from Bornhölm to Öland, and from Gotland to Gotska Sandön). Pooled groups were named after the site contributing the largest number of samples. Biometric data on length $(\mathrm{mm})$ and weight $(\mathrm{g})$ were available for eight of the 15 sites (Table 1). Swansea University, College of Science Ethics Review Committee, provided full approval to Benjamin Whittaker for the genetic analysis of tissue samples already collected by other researchers (STU_BIOL_90920_181018132845_1).

\subsection{DNA extraction and amplification}

DNA was extracted using the Nexttec Isolation kit (Nexttec, UK) following the manufacturer's protocol. The concentration of extracted DNA was quantified using a Nanodrop 2000 (Thermo Fisher Scientific Inc., USA) and diluted with DNA free water to $50 \mathrm{ng} / \mu \mathrm{l}$ where necessary. A $2 \mu \mathrm{l}$ of sample DNA was used for amplification using a QIAGEN Multiplex PCR kit (QIAGEN, UK) in a total reaction volume of $9 \mu 1$. Ten lumpfish specific microsatellite loci (Clu29, Clu34, Clu36, Clu45 and Clu12, Clu26, Clu33, Clu37, Clu40, Clu44 (Skirnisdottir et al., 2013) were genotyped in two separate multiplex reactions (Table S1). Amplification consisted of a single initial activation step at $95^{\circ} \mathrm{C}$ for 15 minutes followed by eight cycles of touchdown PCR denaturation at $94^{\circ} \mathrm{C}$ for 30 seconds, annealing from $64^{\circ} \mathrm{C}$ or $60^{\circ} \mathrm{C}$ to $56^{\circ} \mathrm{C}$ in descending two-cycle steps of $2^{\circ} \mathrm{C}$ and an extension at $72^{\circ} \mathrm{C}$ for 90 seconds, 24 additional cycles with an annealing temperature of $56^{\circ} \mathrm{C}$ and a single final extension at $60^{\circ} \mathrm{C}$ for 30 minutes. An Applied Biosystems ABI3130xl Genetic Analyser (Applied Biosystems, UK) was used to resolve the fragments using GeneScan 500-LIZ(-250) as a size standard. Fragment length was established using GeneMapper v5.0 (Applied Biosystems, UK). Genotyping consistency was validated by repeating PCR, fragment analysis and scoring for $10 \%$ of samples.

\subsection{Estimates of genetic diversity}

We used Microchecker v2.2.3 (Van Oosterhout et al., 2004) to identify null alleles, allele dropout and stutter peaks, and Bayescan v2.1 (Foll \& Gaggiotti, 2008) to test for loci neutrality.

GENEPOP v4.2 (Rousset, 2008) was used to test for linkage disequilibrium, deviations from Hardy-Weinberg equilibrium, and to calculate allelic frequencies across populations. GeneAlEx $v 6.502$ (Peakall \& Smouse, 2012) was used to assess the number of alleles $\left(N_{\mathrm{A}}\right)$, effective alleles $\left(N_{E}\right)$, private alleles $\left(N_{\mathrm{PA}}\right)$, expected $\left(H_{\mathrm{E}}\right)$ and observed heterozygosity $\left(H_{\mathrm{O}}\right)$, and to carry out a Mantel test of genetic isolation by distance.

\subsection{Genetic differentiation, genetic structure and patterns of migration}

We estimated the extent of genetic differentiation by calculating global and pairwise $F_{S T}$ values between populations by 1,000 permutations with a Bonferroni correction $(P<0.00022)$ using Arlequin v3.5.2.2 (Excoffier \& Lischer, 2010). We then conducted an Analysis of Molecular Variance (AMOVA) on pooled groups (separated more than $80 \mathrm{Km}$ ) to partition genetic variation at three hierarchical levels (among populations, within populations, and among individuals), and estimated significance values using 1,000 permutations. To assess population structuring, a Bayesian cluster analysis was conducted in STRUCTURE v2.3.4 (Falush et al., 2007; Hubisz et al. 2009; Pritchard et al., 2000) to estimate the most likely number of genetic clusters $(\mathrm{K})$ informed by individual genotypes. Admixture models with $\mathrm{K}$ values ranging from 2 to 15 were run using twenty iterations, a burn-in length of 10,000 and 50,000 Markov Chain 
178 Monte Carlo repeat simulations to estimate the likelihood of each K value. Results were fed into

179 STRUCTURESELECTOR (Li \& Liu, 2018) to identify the most likely number of clusters present

180 based on the median of means (MedMeaK), maximum of means (MaxMeaK), median of

181 medians (MedMedK) and maximum of medians (MaxMedK) criteria (Puechmaille, 2016). In

182 addition, we used a Bayesian cluster analysis implemented in TESS v2.3.1 (Chen et al., 2007),

183 which explicitly includes spatial information, to identify genetic discontinuities in our study area

184 and estimates admixture proportions without assuming any predefined populations. For this,

185 spatial coordinates were randomly generated for each sample to fall within one standard

186 deviation of the maximum and minimum latitude and longitude of each site (Durand et al., 187 2008). Admixture models were run with 50,000 total sweeps, 10,000 burn-in sweeps, and 200

188 runs per $K_{\max }$ ranging from 2 to 15. The average Deviance Information Criterion (DIC) of the

189 lowest 10 DIC values was calculated for each $K_{\max }$ to assess the most likely number of clusters.

190 Runs within $10 \%$ of the lowest (DIC) for a given $K_{\max }$ were used for analysis. CLUMMP v1.1.2

191 (Jakobsson \& Rosenberg, 2007) was used to average variation between repeated iterations for the

192 most likely K values, and the resulting output was visualised using DISTRUCT v1.1.1

193 (Rosenberg, 2004). A neighbour joining tree was constructed with Populations v1.2.32

194 (Langella, 2002) to further analyse population differentiation using Nei's standard genetic

195 distance with 1,000 bootstraps per locus, and the resulting tree was visualised using TreeView

196 (Page, 2003). Patterns of gene flow were estimated using div-Migrate, which defines a pool of

197 simulated migrants based on the allele frequencies of each population pair and estimates

198 asymmetric gene flow by measuring the genetic differentiation between each population and the

199 migrants pool (Sundqvist et al. 2016). We used the $N m$ statistic (Alcala et al. 2014) that

200 combines elements of $G_{S T}$ and $D$ to calculate directional relative migration and assessed whether

201 gene flow was significantly asymmetric between populations by running 5,000 bootstrap

202 simulations.

203

204

205

206

207

208

209

210

211

212

213

214

215

216

217

218

219

220

221

222

223

\subsection{Effective population size and evidence of genetic bottlenecks}

Estimates of effective population size $\left(N_{\mathrm{e}}\right)$ for sites containing at least 19 individuals were calculated using the Linkage Disequilibrium Model (LDM) with a critical value of 0.02 in NeEstimator v2.1 (Do et al., 2014). Evidence of genetic bottlenecks was evaluated with Bottleneck v2.1 (Cornuet \& Luikart, 1996) using 1,000 replicates under the Two-Phase (TPM) and the Stepwise (SMM) Mutation Models to assess heterozygosity deficiency.

\subsection{Phenotypic variation}

Variation in the length-weight relationship between regions (West Atlantic, $\mathrm{n}=30$; East Atlantic, $\mathrm{n}=65$; English Channel, $\mathrm{n}=60$; Baltic Sea, $\mathrm{n}=40$ ), was examined by regression analysis on log-transformed data. We calculated relative weight $(\mathrm{Wr})$ as the ratio of the observed weight divided by the predicted weight (from the regression obtained above) to obtain an index of body condition that is more appropriate for fish like lumpfish that have an unusual body shape (Nahdi et al., 2016). The most plausible number of age classes represented in the samples, and the mean size at age (Macdonald \& Pitcher, 1979) were calculated through mixture analysis of lengthfrequency data using PAST v3.17 (Hammer et al, 2001). The Von Bertalanffy growth equation (Kirkwood, 1983) was fitted to estimate growth parameters in each region. 
230

231 
232

233

234

235

236

237

238

239

240

241

242

243

244

245

246

247

248

249

250

251

252

253

254

255

256

257

258

259

260

261

262

263

264

265

266

267

268

269

270

271

272

273

274

275

276

277

\section{RESULTS}

\subsection{Population genetic diversity}

All microsatellite loci were polymorphic. The mean number of alleles $\left(N_{A}\right)$ ranged from 4.5 (Ro) to $6.8(\mathrm{Kl}, \mathrm{VB})$, mean expected heterozygosity $\left(H_{E}\right)$ ranged from 0.592 (Öl) to $0.700(\mathrm{Kl})$, and mean $F_{I S}$ varied from -0.056 (Ro) to 0.110 (Öl) across all loci (Table 1). Initial analysis suggested that null alleles might be present at multiple loci (Clu34, Clu36, Clu12, Clu33, Clu37 and Clu40, Table S2). However, repeatedly removing each locus in turn showed little variation in $F_{S T}$ values (Tables S3-S8), and therefore all markers were retained for further analyses. No evidence of departures from neutrality or linkage disequilibrium was found after Bonferroni corrections for multiple tests (Rice, 1989). Deviations from Hardy-Weinberg equilibrium (HWE) were detected at 5 of the 15 sites (Table 1), but these involved only $12 \%$ of loci after Bonferroni correction (Table S9). The mean number of private alleles $\left(N_{P A}\right)$ was relatively low, ranging from 0.00 to 0.40, with sites in the West Atlantic $(\mathrm{FB}=0.30, \mathrm{WB}=0.40)$ and Baltic Sea $(\mathrm{GS}=$ 0.30 ) showing the highest values.

\subsection{Population structure and gene flow}

Global $F_{S T}$ was $0.095(P<0.001)$ indicating a moderate but significant degree of genetic differentiation for a marine fish (Hartl et al., 1997; Ward, 2000; Hutchinson et al., 2001). Results of AMOVA indicated that $83.5 \%$ of molecular variation was due to variation within individuals, $7 \%$ amongst individuals within populations, and $9.5 \%$ amongst populations (Table S10).

Pairwise $F_{S T}$ showed a significant level of genetic differentiation across most populations (Table 2), but populations closer together were genetically similar after Bonferroni correction. On the basis of $F_{S T}$ values, the strongest differentiation was found between West Atlantic and Baltic Sea populations. Results of a Mantel test support the existence of a significant, albeit weak, isolation by distance $\left(R^{2}=0.1229, P=0.01\right)$.

The most likely number of genetically distinct groups $(K)$ ranged from $K=5$ (MedMedK, MedMeaK) to $K=6$ (MaxMedK, MaxMeaK) using STRUCTURESELECTOR (Figure S1). Spatial cluster analysis using TESS suggested a $K_{\max }=10$ (Figure S2), though only six of these genetic groups showed substantial representation, and four groups contributed only $3.3 \%$ to the genetic background. Distinct clusters were detected in the West Atlantic and Baltic Sea by both STRUCTURE and TESS, with a greater level of admixture across the East Atlantic (Figure 1AC). Results were consistent in attributing a genetically unique pattern to the Mid Atlantic, English Channel clusters and a Norwegian site at Averøy. A neighbour joining tree (Figure 2) showed similar patterns to that of the structuring analyses, highlighting the separation between the West Atlantic and Baltic Sea populations, and the higher degree of admixture within the East Atlantic group.

The effective number of migrants $\left(N_{\mathrm{m}}\right)$ ranged from 1.00 between sites in the English Channel to 0.03 between sites in the West Atlantic and Baltic Sea. The exchange of migrants was much higher within genetic clusters than among clusters (Table S11), with the highest levels of gene flow found within the East Atlantic and within the English Channel (Figure 3). The only evidence of moderate asymmetric gene flow was from Norway towards the Faroe Islands $\left(N_{\mathrm{m}}=\right.$ $0.507, P<0.05)$. 


\subsection{Effective population size and evidence of genetic bottlenecks} Estimates of effective population size $\left(N_{\mathrm{e}}\right)$ based on a Linkage Disequilibrium Model (LDM) varied from 19 (Norway) to 70,148 (Denmark; Table S12). Sites with low $N_{\mathrm{e}}$ values $(<75)$ were found across Iceland, Faroe Islands and Norway (Figure 3). A significant deficiency of heterozygotes was identified in Ireland and Scotland using the Single Mutation Model (SMM) in Bottleneck (Wilcoxon signed-rank test, $P=0.0033$ after Bonferroni correction), suggesting that these populations could have undergone a recent genetic bottleneck (Table S13), but this was not detected by the Two-Phase Model of Mutation (TPM).

\subsection{Phenotypic variation}

The relationship between length and weight differed significantly between regions $\left(F_{4,192}=\right.$ 917.2, $P<0.001$; Figure 4). Lumpfish in the Baltic Sea were heavier relative to their size than lumpfish in the East Atlantic and the English Channel (pairwise comparisons: Baltic - East Atlantic, estimate $=-0.090 \pm 0.036, \mathrm{t}=-2.530, P=0.012$; Baltic - English Channel, estimate $=$ $0.145 \pm 0.046, t=-3.171, P=0.002$ ), but were similar to those in the West Atlantic (pairwise comparison Baltic - West Atlantic, estimate $=-0.094 \pm 0.050, t=-1.891, P=0.060$ ). The relative weight of lumpfish differed between regions $\left(F_{3,191}=2.841, P=0.039\right)$ and was highest in the Baltic Sea and the West Atlantic, and lowest in the East Atlantic and the English Channel.

Mixture analysis identified multiple plausible age classes present amongst lumpfish sampled in the Baltic Sea (7 age classes), East Atlantic (4 age classes) and English Channel (3 age classes), but only a single plausible age class in the West Atlantic. Based on the parameters of the Von Bertalanffy Growth equation, the maximum age was estimated to be 6.0 years for Baltic populations, $5.7 \mathrm{yrs}$ for populations in the East Atlantic and $7.5 \mathrm{yrs}$ for southern populations spawning in the English Channel. Fitted growth equations differed significantly between regions (Table 3), with lumpfish in the Baltic Sea showing the slowest growth and those in the English Channel showing the fastest. 
307

308

309

310

311

312

313

314

315

316

317

318

319

320

321

322

323

324

325

326

327

328

329

330

331

332

333

334

335

336

337

338

339

340

341

342

343

344

345

346

347

348

349

350

351

352

\section{DISCUSSION}

Our study reveals a significant degree of population structuring in lumpfish, which is consistent with moderate isolation by distance - as seen in other marine fish (e.g. Ward, 2000; Hutchinson et al., 2001), and which should inform the translocation of this species across salmon farms. Genetically distinct groups were found in the West Atlantic (USA, Canada), Mid Atlantic (Iceland), East Atlantic (Faroe Islands, Ireland, Scotland, Norway, Denmark), English Channel, Averøy (Norway) and Baltic Sea (Sweden). Whilst significant gene flow was detected within each of these groups, little exchange of migrants was found between these areas.

Our results also indicate the existence of significant phenotypic differences across the range, that mimic to some extent the observed genetic differences. Lumpfish typically mature at 3-5 years of age, although some populations mature after only 2 years and some individuals may exceptionally live up to 14 years (reviewed in Powell et al., 2018a,b). Lumpfish from the Baltic Sea were not only genetically distinct, they were also smaller, grew at a slower rate, and weighed more relative to their size than lumpfish from the North Atlantic. Although our growth estimates were based on length frequency data and did not distinguish between males and females, they are in line with estimates based on mark and recapture studies in Norway and Iceland $(L \infty=527 \pm$ $64 \mathrm{~mm}, K=0 \cdot 26 \pm 0 \cdot 14$ year $^{-1}$; Kasper et al., 2014), and suggest that Baltic lumpfish grow more slowly and mature at a much smaller size (c. $150 \mathrm{~g}$ ) than lumpfish from the North Atlantic (2.0$3.0 \mathrm{Kg}$ ). The slow growth shown by Baltic lumpfish may be of interest for selective breeding programmes in aquaculture, as slow growing cleaner fish may be better suited for feeding on sea lice (Powell et al., 2018a); however, given their markedly different genetic structure, care should be taken to ensure that Baltic lumpfish do not introgress into Atlantic lumpfish populations via farm escapes.

Pampoulie et al. (2014) first suggested that lumpfish in the West and East Atlantic were separated by cold southward polar currents, and that populations in the Baltic Sea may have become isolated during the Last Glacial Maximum. Though our analysis supports this broad division, it also indicates a finer population structure, revealing that lumpfish in the Mid Atlantic and English Channel are genetically distinct from other populations. The conclusion of our genetic analyses is consistent with recent tagging studies in Norway and Iceland showing that whilst lumpfish can move offshore to feed, they return to spawn in their home waters (Kennedy et al., 2015; Kennedy et al., 2016) and do not migrate between Iceland and Norway (Kasper et al., 2014). There is little information on southern lumpfish populations, though lumpfish in the English Channel appear to spawn earlier in the season than populations further north (Powell et al., 2018b), probably due the warmer temperatures and better feeding opportunities, which are known to influence maturation and spawning of lumpfish (Hedeholm et al., 2017). It is thus possible that the warmer waters found at the species' southern range may favour an early spawning and lead to some degree of reproductive isolation, hence limiting gene flow along a latitudinal gradient. With the exception of the Averøy population, the remaining sites in the East Atlantic appear to be genetically uniform, as reported along the Norwegian coast (Jónsdóttir et al., 2017).

The level of genetic diversity, and therefore the ability to adapt and respond to selection, differed substantially among regions. Our estimates of effective population size, the first for this species, 
353

354

355

356

357

358

359

360

361

362

363

364

365

366

367

368

369

370

371

372

373

374

375

376

377

378

379

380

381

382

383

384

385

386

387

388

389

390

391

392

393

394

395

396

397

398

were particularly low across the North East Atlantic (Iceland, $N_{\mathrm{e}}=43$; Faroe Islands, $N_{\mathrm{e}}=30$; Norway, mean $N_{\mathrm{e}}=51$ ), and some evidence of genetic bottlenecks was also detected at sites in Ireland and Scotland, though the evidence for this was not strong. The North East Atlantic supports one of the largest lumpfish roe fisheries (Jónsdóttir et al., 2018), with a production of 4,000 tonnes of roe per year (Johannesson, 2006). Given a maximum yield of c. $4 \mathrm{~kg}$ roe/female (Johannesson, 2006), this level of harvest likely surpasses 1 million mature females every year. Harvesting for lumpfish roe is both size and sex-selective, which increases the vulnerability of populations to over-exploitation (Hoenig \& Hewitt, 2005; Ratner \& Lande, 2001) and may explain the low estimates of effective population size found across this area. The North East Atlantic populations appear to be small and reducing pressure on these stocks would decrease the risk of over exploitation.

Although our estimates of effective population size are based on a relatively low number of genetic markers (selected to allow comparisons with previous studies, Pampoulie et al., 2014; Jónsdóttir et al., 2017), and need to be interpreted with caution, estimates based on the LD method using similar conditions to ours (10 loci with an average of 10 alleles and a sample size of 50 individuals) have proved accurate for small effective population sizes $\left(N_{\mathrm{e}} \sim 100\right)$ (Waples and Do 2010). This was the case for most of our populations, with the exception of three $N_{\mathrm{e}}$ estimates that resulted in infinity. This is likely to have been due to the use of the LD method, which is generally efficient for small populations, but may be unable to detect weak drift signals in larger populations, and can be very sensitive to small violations of model assumptions (Waples and Do 2010). We therefore recommend that further analyses are carried out with a larger number of markers (e.g. genome wide distributed SNPs), as this may allow more accurate estimates of effective population sizes and other demographic parameters.

\subsection{Conclusions and management implications}

By 2020 c. 50 million lumpfish will be required by the salmon farming industry (Powell et al., 2018a; Treasurer, 2018) and most of these will come from the stripping of wild broodstock (Wittwer \& Treasurer, 2018) caught in Iceland and Norway, and then shipped as eggs or larvae to salmon farms elsewhere. Information on lumpfish escapees is lacking but corkwing wrasse (Symphodus melops) deployed as cleaner fish in Norway have recently been found to escape and hybridise with local populations (Faust et al., 2018), and the same could happen with lumpfish. Efforts should thus be made to reduce the risk of lumpfish escaping from fish farms and interbreeding with local populations, as high propagule pressure associated with open-net pens is the single most important factor determining the impact of escapees (Consuegra et al., 2011).

Our study suggests that lumpfish translocations should be restricted within genetically homogenous groups to reduce the risk of genetic introgression between native and non-native populations. In this sense, lumpfish from some areas of Norway, and particularly from Iceland, may be ill-suited for deployment in Ireland, Scotland and the Faroe Islands, and vice-versa. Ultimately, closing the breeding cycle of the species in captivity, and producing sterile lumpfish for deployment in salmon farms, must be a research priority for both the conservation of the species and the cleaner fish industry (Powell et al., 2018a), as this will lessen dependency on wild broodstock and reduce the risk of genetic introgression. 


\section{AKNOWLEDGMENTS}

402 We are indebted to Majbritt Bolton-Warberg, Danny Boyce, Werner Forster, Gus Galloway, Ása 403 Johannesen, Lars Jørgen Ulvan, Niklas Larson, Marine Harvest Scotland, Michael Pietrak, Adam 404 Rainsden and Peter Rask for supplying tissue samples. We are also grateful to Chloe Robinson, 405 Niall Coates, Christine Gray, Craig Pooley and Ian Tew for assistance in optimising primers and 406 processing samples.

407

408

409 


\section{REFERENCES}

Aaen, S.M., Helgesen, K.O., Bakke, M.J., Kaur, K., \& Horsberg, T.E. (2015). Drug resistance in sea lice: A threat to salmonid aquaculture. Trends in Parasitology 31, 72-81.

Alcala N., Goudet J., \& Vuilleumier, S. (2014). On the transition of genetic differentiation from isolation to panmixia: What we can learn from $G_{S T}$ and $D$. Theoretical Population Biology 93, 75-84.

Bolton-Warberg, M., O'Sullivan, S.M., Power, A.M., Moore, A.I., Wilson, L., Sproll, F., Schlittenhardt, S., Yusof, M.F.B.M., D'Arcy, J., Jackson, D., \& Fitzpatrick, R. (2018). Cleaner fish use in Ireland. In Cleaner Fish Biology and Aquaculture Applications (Ed. J.W. Treasurer), pp. 386-413. 5M Publishing Ltd., Sheffield.

Chen, C., Durand, E., Forbes, F., \& François, O. (2007). Bayesian clustering algorithms ascertaining spatial population structure: A new computer program and a comparison study. Molecular Ecology Notes, 7, 747-756.

Consuegra, S., Phillips, N., Gajardo, G., \& Garcia de Leaniz, C. (2011). Winning the invasion roulette: Escapes from fish farms increase admixture and facilitate establishment of nonnative rainbow trout. Evolutionary Applications 4, 660-671.

Consuegra, S., Pooley, C., Powell, A., Keay, A., Galloway, G., Cockerill, D., \& Garcia de Leaniz, C. (2015). A traceability and genetic screening programme for sustainable breeding of lumpfish (Cyclopterus lumpus) for sea lice control in salmon farming. Proceedings of Aquaculture Europe 2015, Rotterdam, European Aquaculture Society, pp. 167.

Cornuet, J.M., \& Luikart, G. (1996). Description and power analysis of two tests for detecting recent population bottlenecks from allele frequency data. Genetics 144, 2001-2014.

Davenport, J. (1985). Synopsis of biological data on the lumpsucker Cyclopterus lumpus (Linnaeus, 1758). FAO Fisheries Synopsis (Vol. 147).

Do, C., Waples, R.S., Peel, D., Macbeth, G.M., Tillett, B.J., \& Ovenden, J.R. (2014). NeEstimator v2: Re-implementation of software for the estimation of contemporary effective population size (Ne) from genetic data. Molecular Ecology Resources 14, 209214.

Excoffier, L., \& Lischer, H.E.L. (2010). Arlequin suite ver 3.5: A new series of programs to perform population genetics analyses under Linux and Windows. Molecular Ecology Resources 10, 564-567.

Falush, D., Stephens, M., \& Pritchard, J.K. (2003). Inference of population structure using multilocus genotype data: Linked loci and correlated allele frequencies. Genetics 164, $1567-1587$.

Falush, D., Stephens, M., \& Pritchard, J.K. (2007). Inference of population structure using multilocus genotype data: Dominant markers and null alleles. Molecular Ecology Notes 7, 574-578.

Faust, E., Halvorsen, K.T., Andersen, P., Knutsen, H., \& André, C. (2018). Cleaner fish escape salmon farms and hybridize with local wrasse populations. Royal Society Open Science 5, 171752.

Foll, M., \& Gaggiotti, O. (2008). A genome-scan method to identify selected loci appropriate for both dominant and codominant markers: A Bayesian perspective. Genetics 180, 977-993.

Garcia-Mayoral, E., Olsen, M., Hedeholm, R., Post, S., Nielsen, E.E., \& Bekkevold, D. (2016). Genetic structure of West Greenland populations of lumpfish Cyclopterus lumpus. Journal of Fish Biology 89, 2625-2642. 
456

457

458

459

460

461

462

463

464

465

466

467

468

469

470

471

472

473

474

475

476

477

478

479

480

481

482

483

484

485

486

487

488

489

490

491

492

493

494

495

496

497

498

499

500

501

Gilbey, J., Coughlan, J., Wennevik, V., Prodöhl, P., Stevens, J.R., Garcia de Leaniz, C., Ensing, D., Cauwelier, E., Cherbonnel, C., Consuegra, S., Coulson, M.W., Cross, T.F., Crozier, W., Dillane, E., Ellis, J.S., García-Vázquez, E., Griffiths, A.M., Gudjonsson, S., Hindar, K., Karlsson, S., Knox, D., Machado-Schiaffino, G., Meldrup, D., Eg Nielsen, E., Ólafsson, K., Primmer, C.R., Prusov, S., Stradmeyer, L., Vähä, J.-P., Veselov, A.J., Webster, L.M.I., McGinnity, P. \& Verspoor, E. (2017). A microsatellite baseline for genetic stock identification of European Atlantic salmon (Salmo salar L.). ICES Journal of Marine Science 75, 662-674.

Halvorsen, K.T., Larsen, T., Sørdalen, T.K., Vøllestad, L.A., Knutsen, H., \& Olsen, E.M. (2017). Impact of harvesting cleaner fish for salmonid aquaculture assessed from replicated coastal marine protected areas. Marine Biology Research 13, 359-369.

Hammer, Ø., Harper, D.A.T., \& Ryan, P.D. (2001). PAST: Paleontological Statistics Software Package for Education and Data Analysis. Palaeontologia Electronica 4, 1-9.

Hedeholm, R.B., Post, S., \& Grønkjær, P. (2017). Life history trait variation of Greenland lumpfish (Cyclopterus lumpus) along a $1600 \mathrm{~km}$ latitudinal gradient. Polar Biology 40, 2489-2498.

Hoenig, J.M., \& Hewitt, D.A. (2005). What can we learn about mortality from sex ratio data? a look at lumpfish in Newfoundland. Transactions of the American Fisheries Society 134, 754-761.

Hubisz, M.J., Falush, D., Stephens, M., \& Pritchard, J.K. (2009). Inferring weak population structure with the assistance of sample group information. Molecular Ecology Resources 9, 1322-1332.

Imsland, A.K., Reynolds, P., Eliassen, G., Hangstad, T.A., Nytrø, A.V., Foss, A., Vikingstad, E., \& Elvegård, T.A. (2014). Notes on the behaviour of lumpfish in sea pens with and without Atlantic salmon present. Journal of Ethology 32, 117-122.

Imsland, A.K., Reynolds, P., Eliassen, G., Mortensen, A., Hansen, Ø.J., Puvanendran, V., Hangstad, T.A., Jónsdóttir, Ó.D.B., Emaus, P-A., Elvegård, T.A., Lemmens, S.C.A., Rydland, R., Nytrø, A.V., \& Jonassen, T.M. (2016). Is cleaning behaviour in lumpfish (Cyclopterus lumpus) parentally controlled? Aquaculture 459, 156-165.

Jakobsson, M., \& Rosenberg, N. A. (2007). CLUMPP: A cluster matching and permutation program for dealing with label switching and multimodality in analysis of population structure. Bioinformatics 23, 1801-1806.

Jansson, E., Quintela, M., Dahle, G., Albretsen, J., Knutsen, H., André, C., Strand, Å., Mortensen, S., Taggart, J.B., Karlsbakk, E., Kvamme, B.O., \& Glover, K.A. (2017). Genetic analysis of goldsinny wrasse reveals evolutionary insights into population connectivity and potential evidence of inadvertent translocation via aquaculture. ICES Journal of Marine Science 74, 2135-2147.

Johannesson, J. (2006). Lumpfish caviar- from vessel to consumer. FAO Fisheries Technical Paper. No. 485, 71.

Jonassen, T., Remen, M., Lekva, A., Steinarsson, A., \& Árnason, T. (2018a). Transport of lumpfish and wrasse. In Cleaner Fish Biology and Aquaculture Applications (Ed. J.W. Treasurer), pp. 319-335. 5M Publishing Ltd., Sheffield.

Jonassen, T.M., Lein, I., \& Nytrø, A.V. (2018b). Hatchery management of lumpfish. In Cleaner Fish Biology and Aquaculture Applications (Ed. J.W. Treasurer), pp. 122-146. 5M Publishing Ltd., Sheffield.

Johannesen, Á., Arge, R., \& Eliasen, K. (2018). Rearing, farm application and behaviour of 
502

503

504

505

506

507

508

509

510

511

512

513

514

515

516

517

518

519

520

521

522

523

524

525

526

527

528

529

530

531

532

533

534

535

536

537

538

539

540

541

542

543

544

545

546

547 lumpfish (Cyclopterus lumpus) in the Faroes. In Cleaner Fish Biology and Aquaculture Applications (Ed. J.W. Treasurer), pp. 435-449. 5M Publishing Ltd., Sheffield.

Jónsdóttir, Ó.D.B., Schregel, J., Hagen, S.B., Tobiassen, C., Aarnes, S.G., \& Imsland, A.K. (2017). Population genetic structure of lumpfish along the Norwegian coast: aquaculture implications. Aquaculture International 1, 1-12.

Jónsdóttir Ó.D.B., Imsland, A.K., \& Kennedy, J. (2018). Lumpfish biology, genetics, use of microsatellites and SNP for population genetics and parental assignment, seek for QTLs. In Cleaner Fish Biology and Aquaculture Applications (Ed. J.W. Treasurer), pp. 218-228. 5M Publishing Ltd., Sheffield.

Kasper, J.M., Bertelsen, B., Ólafsson, H.G., Holst, J.C., Sturlaugsson, J., \& Jónsson, S.P. (2014). Observations of growth and postspawning survival of lumpfish Cyclopterus lumpus from mark-recapture studies. Journal of Fish Biology 84, 1958-1963.

Kennedy, J., Jónsson, S.P., Kasper, J.M., \& Olafsson, H.G. (2015). Movements of female lumpfish (Cyclopterus lumpus) around Iceland. ICES Journal of Marine Science 72, 880889.

Kennedy, J., Jónsson, S.P., Ólafsson, H.G., \& Kasper, J.M. (2016). Observations of vertical movements and depth distribution of migrating female lumpfish (Cyclopterus lumpus) in Iceland from data storage tags and trawl surveys. ICES Journal of Marine Science 73, $1160-1169$.

Kirkwood, G.P. (1983). Estimation of von Bertalanffy growth curve parameters using both length increment and age-length data. Canadian Journal of Fisheries and Aquatic Sciences $40,1405-1411$.

Kousoulaki, K., Treasurer, J., \& FitzGerald, R. (2018). Fisheries for cleaner fish in Europe. In Cleaner Fish Biology and Aquaculture Applications (Ed. J.W. Treasurer), pp. 330-357. 5M Publishing Ltd., Sheffield.

Langella, O. (2002) Populations 1.2.32. CNRS UPR9034. (available at: http://bioinformatics.org/project/?group_id=84; last accessed 27 April 2018)

Lees, F., Baillie, M., Gettinby, G., \& Revie, C.W. (2008). The efficacy of emamectin benzoate against infestations of Lepeophtheirus salmonis on farmed Atlantic salmon (Salmo salar L) in Scotland, 2002-2006. PLoS ONE 3(2).

Li, Y.L., \& Liu, J.X. (2018). StructureSelector: A web-based software to select and visualize the optimal number of clusters using multiple methods. Molecular Ecology Resources 18, 176177.

Lorance, P., Cook, R., Herrera, J., de Sola, L., Florin, A., \& Papaconstantinou, C. (2015). Cyclopterus lumpus. The IUCN Red List of Threatened Species 2015 e.T18237406A45078284. [Cited 27 Apr 2018.] Available from URL: http://www.iucnredlist.org/details/18237406/1

Macdonald, P.D.M., \& Pitcher, T.J. (1979). Age-groups from size-frequency data: a versatile and efficient method of analyzing distribution mixtures. Journal of the Fisheries Research Board of Canada 36, 987-1001.

Myers, R.A., \& Sjare, B. (1995). An analysis of lumpfish from data on individual fishermen in the Newfoundland region. DFO Atlantic Fisheries Research Document, 95/96.

Nahdi, A.A., Garcia de Leaniz, C., \& King, A.J. (2016). Spatio-temporal variation in lengthweight relationships and condition of the ribbonfish Trichiurus lepturus (Linnaeus, 1758): Implications for fisheries management. PloS ONE 11, e0161989.

Page, R.D.M. (2003). Inferring evolutionary relationships: visualizing phylogenetic trees using 
TreeView. Current Protocols in Bioinformatics 6, Unit 6.2.

Pampoulie, C., Skirnisdottir, S., Olafsdottir, G., Helyar, S.J., Thorsteinsson, V., Jónsson, S.P., Fréchet, A., Durif, C.M., Sherman, S., Lampart-Kałużniacka, M. (2014). Genetic structure of the lumpfish Cyclopterus lumpus across the North Atlantic. ICES Journal of Marine Science 71, 2390-2397.

Peakall, R., \& Smouse, P.E. (2012). GenALEx 6.5: Genetic analysis in Excel. Population genetic software for teaching and research-an update. Bioinformatics 28, 2537-2539.

Powell, A., Treasurer, J.W., Pooley, C.L., Keay, A.J., Lloyd, R., Imsland, A. K., \& Garcia de Leaniz, C. (2018a). Use of lumpfish for sea-lice control in salmon farming: challenges and opportunities. Reviews in Aquaculture 10, 683-702.

Powell, A., Pooley, C., Scolamacchia, M., \& Garcia de Leaniz, C. (2018b). Review of lumpfish biology. In Cleaner Fish Biology and Aquaculture Applications (Ed. J.W. Treasurer), pp. 98-121. 5M Publishing Ltd., Sheffield.

Pritchard, J.K., Stephens, M., \& Donnelly, P. (2000). Inference of population structure using multilocus genotype data. Genetics $155,945-959$.

Puechmaille, S.J. (2016). The program STRUCTURE does not reliably recover the correct population structure when sampling is uneven: Subsampling and new estimators alleviate the problem. Molecular Ecology Resources 16, 608-627.

R Development Core Team. (2013). R Software. R: A Language and Environment for Statistical Computing.

Ratner, S., \& Lande, R. (2001). Demographic and evolutionary responses to selective harvesting in populations with discrete generations. Ecology 82, 3093-3104.

Rice, W.R. (1989). Analyzing tables of statistical tests. Evolution 43, 223-225.

Rosenberg, N.A. (2004). DISTRUCT: A program for the graphical display of population structure. Molecular Ecology Notes 4, 137-138.

Rousset, F. (1997). Genetic differentiation and estimation of gene flow from F-statistics under isolation by distance. Genetics 145, 1219-1228.

Rousset, F. (2008). GENEPOP'007: A complete re-implementation of the GENEPOP software for Windows and Linux. Molecular Ecology Resources 8, 103-106.

Skirnisdottir, S., Olafsdottir, G., Olafsson, K., Jendrossek, T., Lloyd, H.a.D., Helyar, S., Pampoulie, Danielsdottir, A.K., \& Kasper, J.M. (2013). Twenty-two novel microsatellite loci for lumpfish (Cyclopterus lumpus). Conservation Genetics Resources 5, 177-179.

Steinarsson, A., \& Arnason, T. (2018). Rearing of cleaner fish use in Iceland. In Cleaner Fish Biology and Aquaculture Applications (Ed. J.W. Treasurer), pp. 414-428. 5M Publishing Ltd., Sheffield.

Sundqvist, L., Keenan, K., Zackrisson, M., Prodöhl, P., \& Kleinhans, D. (2016). Directional genetic differentiation and relative migration. Ecology and Evolution 6, 3461-3475.

Torrissen, O., Jones, S., Asche, F., Guttormsen, A., Skilbrei, O.T., Nilsen, F., Horsberg, T.E., \& Jackson, D. (2013). Salmon lice - impact on wild salmonids and salmon aquaculture. Journal of Fish Diseases 36, 171-194.

Treasurer, J.W. (2002). A review of potential pathogens of sea lice and the application of cleaner fish in biological control. Pest Management Science 58, 546-558.

Treasurer, J.W. (2018). An introduction to sea lice and the rise of cleaner fish. Cleaner Fish Biology and Aquaculture Applications. In Cleaner Fish Biology and Aquaculture Applications (Ed. J.W. Treasurer), pp. 3-24. 5M Publishing Ltd., Sheffield.

Treasurer, J., Prickett, R., Zietz, M., Hempleman, C., \& Garcia de Leaniz, C. (2018). Cleaner 
594 fish rearing and deployment in the UK. In Cleaner Fish Biology and Aquaculture

595

596

597

598

599

600

601

602

603

604

605
Applications (Ed. J.W. Treasurer), pp. 376-391. 5M Publishing Ltd., Sheffield.

Van Oosterhout, C., Hutchinson, W.F., Wills, D.P.M., \& Shipley, P. (2004). MICRO-

CHECKER: Software for identifying and correcting genotyping errors in microsatellite data. Molecular Ecology Notes 4, 535-538.

Waples, R.S., \& Do, C. (2010). Linkage disequilibrium estimates of contemporary $N_{\mathrm{e}}$ using highly variable genetic markers: a largely untapped resource for applied conservation and evolution. Evolutionary Applications 3, 244-262.

Ward, R.D. (2000). Genetics in fisheries management. Hydrobiologia 420, 191-200.

Wittwer, C., \& Treasurer, J. (2018). Egg collection by hand-stripping and natural spawning of lumpfish Cyclopterus lumpus broodstock. In Cleaner Fish Biology and Aquaculture Applications (Ed. J.W. Treasurer), pp. 147-160. 5M Publishing Ltd., Sheffield. 


\section{Table $\mathbf{1}$ (on next page)}

Study sites

Details of study sites sampled for lumpfish ( $N$ : sample size for genetic analysis; $N b$ : sample size for biometric analysis; $N_{A}=$ mean number of alleles $( \pm \mathrm{SE}), N_{E}=$ mean number of effective alleles, $N_{P A}=$ number of private alleles, $H_{O}=$ observed heterozygosity, $H_{E}=$ expected heterozygosity, $F_{I S}=$ fixation index; $*$ denotes deviation from HWE due to heterozygote deficiency after Bonferroni correction at $P<0.0033$ 
1 Table 1. Details of study sites sampled for lumpfish ( $N$ : sample size for genetic analysis; $N b$ :

2 sample size for biometric analysis; $N_{A}=$ mean number of alleles $( \pm \mathrm{SE}), N_{E}=$ mean number of

3 effective alleles, $N_{P A}=$ number of private alleles, $H_{O}=$ observed heterozygosity, $H_{E}=$ expected

4 heterozygosity, $F_{I S}=$ fixation index; *denotes deviation from HWE due to heterozygote

5 deficiency after Bonferroni correction at $P<0.0033$

6

\begin{tabular}{|c|c|c|c|c|c|c|c|c|c|c|c|}
\hline Year & Country & Site & Lat. & Long. & $N \mathrm{Nb}$ & & $N_{E}$ & $N_{P A}$ & $H_{O}$ & $H_{E}$ & $F_{I S}$ \\
\hline 2016 & USA & $\begin{array}{l}\text { Frenchman Bay } \\
\text { (FB) }\end{array}$ & 44.3 & -68.15 & $30-$ & $\begin{array}{l}\text { mean } \\
\pm \mathrm{SE}\end{array}$ & $\begin{array}{lr}6.0 & 3.100 \\
0.775 & 0.548\end{array}$ & $\begin{array}{l}0.300 \\
0.213\end{array}$ & $\begin{array}{l}0.566 \\
0.058\end{array}$ & $\begin{array}{l}0.613 \\
0.044\end{array}$ & $\begin{array}{l}0.100 \\
0.050\end{array}$ \\
\hline 2016 & USA & $\begin{array}{l}\text { Cobscook Bay } \\
\text { (CB) }\end{array}$ & 44.90 & -67.05 & $30-$ & $\begin{array}{l}\text { mean } \\
\pm \mathrm{SE}\end{array}$ & $\begin{array}{lr}6.1 & 3.452 \\
0.862 & 0.456\end{array}$ & $\begin{array}{l}0.100 \\
0.100\end{array}$ & $\begin{array}{l}0.640 \\
0.063\end{array}$ & $\begin{array}{l}0.668 \\
0.038\end{array}$ & $\begin{array}{l}0.078 \\
0.055\end{array}$ \\
\hline 2016 & Canada & $\begin{array}{l}\text { Witless Bay } \\
\text { (WB)* }\end{array}$ & 47.21 & -52.69 & 3030 & $\begin{array}{l}\text { mean } \\
\pm \mathrm{SE}\end{array}$ & $\begin{array}{lr}6.7 & 3.459 \\
0.8700 .425\end{array}$ & $\begin{array}{l}0.400 \\
0.163\end{array}$ & $\begin{array}{l}0.630 \\
0.049\end{array}$ & $\begin{array}{l}0.673 \\
0.036\end{array}$ & $\begin{array}{l}0.080 \\
0.050\end{array}$ \\
\hline 2016 & Iceland & $\begin{array}{l}\text { Hafnir } \\
(\mathrm{Ha})\end{array}$ & 63.93 & -22.69 & $30-$ & $\begin{array}{l}\text { mean } \\
\pm \mathrm{SE}\end{array}$ & $\begin{array}{lr}5.5 & 2.971 \\
0.500 & 0.222\end{array}$ & $\begin{array}{l}0.000 \\
0.000\end{array}$ & $\begin{array}{l}0.637 \\
0.041\end{array}$ & $\begin{array}{l}0.643 \\
0.031\end{array}$ & $\begin{array}{l}0.019 \\
0.050\end{array}$ \\
\hline 2016 & Faroe Is. & $\begin{array}{l}\text { Klasvík } \\
(\mathrm{K} 1)^{*}\end{array}$ & 62.23 & -6.58 & $30-$ & $\begin{array}{l}\text { mean } \\
\pm \mathrm{SE}\end{array}$ & $\begin{array}{lr}6.8 & 3.713 \\
0.3590 .453\end{array}$ & $\begin{array}{l}0.200 \\
0.133\end{array}$ & $\begin{array}{l}0.668 \\
0.049\end{array}$ & $\begin{array}{l}0.700 \\
0.030\end{array}$ & $\begin{array}{l}0.065 \\
0.047\end{array}$ \\
\hline 2014 & Ireland & $\begin{array}{l}\text { Ventry Bay } \\
\text { (VB) }\end{array}$ & 52.20 & -10.12 & 3026 & $\begin{array}{l}\text { mean } \\
\pm \mathrm{SE}\end{array}$ & $\begin{array}{lr}6.8 & 3.255 \\
0.3890 .346\end{array}$ & $\begin{array}{l}0.100 \\
0.100\end{array}$ & $\begin{array}{l}0.647 \\
0.056\end{array}$ & $\begin{array}{l}0.658 \\
0.038\end{array}$ & $\begin{array}{l}0.032 \\
0.050\end{array}$ \\
\hline 2017 & Scotland & $\begin{array}{l}\text { Outer Hebrides } \\
(\mathrm{OH})\end{array}$ & 58.16 & -6.38 & 3018 & $\begin{array}{l}\text { mean } \\
\pm \mathrm{SE}\end{array}$ & $\begin{array}{lr}6.5 & 3.247 \\
0.453 & 0.448\end{array}$ & $\begin{array}{l}0.000 \\
0.000\end{array}$ & $\begin{array}{l}0.623 \\
0.055\end{array}$ & $\begin{array}{l}0.644 \\
0.041\end{array}$ & $\begin{array}{l}0.060 \\
0.036\end{array}$ \\
\hline 2015 & England & $\begin{array}{l}\text { Weymouth } \\
\text { (We) }\end{array}$ & 50.61 & -2.46 & 3030 & $\begin{array}{l}\text { mean } \\
\pm \mathrm{SE}\end{array}$ & $\begin{array}{lr}5.8 & 2.979 \\
0.5930 .423\end{array}$ & $\begin{array}{l}0.000 \\
0.000\end{array}$ & $\begin{array}{l}0.607 \\
0.062\end{array}$ & $\begin{array}{l}0.597 \\
0.059\end{array}$ & $\begin{array}{l}-0.012 \\
0.053\end{array}$ \\
\hline 2015 & England & $\begin{array}{l}\text { Guernsey } \\
(\mathrm{Gu})\end{array}$ & 49.47 & -2.59 & 3030 & $\begin{array}{l}\text { mean } \\
\pm \mathrm{SE}\end{array}$ & $\begin{array}{lr}5.6 & 3.068 \\
0.4760 .431\end{array}$ & $\begin{array}{l}0.000 \\
0.000\end{array}$ & $\begin{array}{l}0.618 \\
0.083\end{array}$ & $\begin{array}{l}0.608 \\
0.055\end{array}$ & $\begin{array}{l}0.032 \\
0.084\end{array}$ \\
\hline 2017 & Norway & $\begin{array}{l}\text { Namsen } \\
(\mathrm{Na})\end{array}$ & 59.15 & 6.01 & 2121 & $\begin{array}{l}\text { mean } \\
\pm \mathrm{SE}\end{array}$ & $\begin{array}{lr}6.3 & 3.080 \\
0.5390 .470\end{array}$ & $\begin{array}{l}0.100 \\
0.100\end{array}$ & $\begin{array}{l}0.576 \\
0.076\end{array}$ & $\begin{array}{l}0.614 \\
0.050\end{array}$ & $\begin{array}{l}0.105 \\
0.078\end{array}$ \\
\hline 2016 & Norway & $\begin{array}{l}\text { Averøy } \\
\text { (Av) }\end{array}$ & 63.05 & 7.48 & $30-$ & $\begin{array}{l}\text { mean } \\
\pm \mathrm{SE}\end{array}$ & $\begin{array}{lr}5.7 & 3.077 \\
0.4960 .336\end{array}$ & $\begin{array}{l}0.000 \\
0.000\end{array}$ & $\begin{array}{l}0.677 \\
0.051\end{array}$ & $\begin{array}{l}0.638 \\
0.038\end{array}$ & $\begin{array}{l}-0.038 \\
0.030\end{array}$ \\
\hline 2015 & Norway & $\begin{array}{l}\text { Rogaland } \\
\text { (Ro) }\end{array}$ & 64.45 & 11.41 & 19 - & $\begin{array}{l}\text { mean } \\
\pm \mathrm{SE}\end{array}$ & $\begin{array}{lr}4.5 & 2.625 \\
0.342 & 0.291\end{array}$ & $\begin{array}{l}0.000 \\
0.000\end{array}$ & $\begin{array}{l}0.600 \\
0.071\end{array}$ & $\begin{array}{l}0.594 \\
0.026\end{array}$ & $\begin{array}{l}-0.056 \\
0.046\end{array}$ \\
\hline 2012 & Denmark & $\begin{array}{l}\text { Køge Bay } \\
(\mathrm{KB})^{*}\end{array}$ & 55.46 & 12.18 & $30-$ & $\begin{array}{l}\text { mean } \\
\pm \mathrm{SE}\end{array}$ & $\begin{array}{lr}5.7 & 3.168 \\
0.423 & 0.273\end{array}$ & $\begin{array}{l}0.000 \\
0.000\end{array}$ & $\begin{array}{l}0.626 \\
0.036\end{array}$ & $\begin{array}{l}0.660 \\
0.033\end{array}$ & $\begin{array}{l}0.067 \\
0.029\end{array}$ \\
\hline 2017 & Sweden & $\begin{array}{l}\text { Öland } \\
\text { (Öl)* }\end{array}$ & 55.72 & 16.39 & 1616 & $\begin{array}{l}\text { mean } \\
\pm \mathrm{SE}\end{array}$ & $\begin{array}{lr}4.7 & 2.838 \\
0.4230 .320\end{array}$ & $\begin{array}{l}0.100 \\
0.100\end{array}$ & $\begin{array}{l}0.548 \\
0.077\end{array}$ & $\begin{array}{l}0.592 \\
0.061\end{array}$ & $\begin{array}{l}0.110 \\
0.073\end{array}$ \\
\hline
\end{tabular}




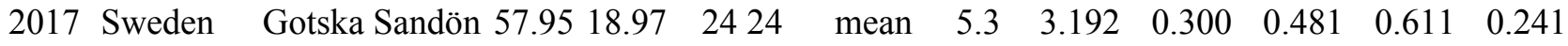

\begin{tabular}{lllllll}
$(\mathrm{GS})^{*}$ & $\pm \mathrm{SE}$ & 0.4480 .449 & 0.213 & 0.073 & 0.064 & 0.081 \\
\hline
\end{tabular}

7

8 


\section{Table 2 (on next page)}

$F_{S T}$ values

Pairwise $F_{S T}$ values (lower) and Bonferroni adjusted $P$ values (upper; Bonferroni correction $P<$ 0.00022 ) between 15 study populations of lumpfish distributed across the natural range of the species using 10 microsatellite loci. 
1 Table 2. Pairwise $F_{S T}$ values (lower) and Bonferroni adjusted $P$ values (upper; Bonferroni 2 correction $P<0.00022$ ) between 15 study populations of lumpfish distributed across the natural 3 range of the species using 10 microsatellite loci. 4

\begin{tabular}{llllllllllllllll}
\hline & $\mathrm{FB}$ & $\mathrm{CB}$ & $\mathrm{WB}$ & $\mathrm{Ha}$ & $\mathrm{Kl}$ & $\mathrm{VB}$ & $\mathrm{OH}$ & $\mathrm{We}$ & $\mathrm{Gu}$ & $\mathrm{Na}$ & $\mathrm{Av}$ & $\mathrm{Ro}$ & $\mathrm{KB}$ & $\mathrm{O} 1$ & $\mathrm{GS}$ \\
\hline $\mathrm{FB}$ & & 0.036 & 0.000 & 0.000 & 0.000 & 0.000 & 0.000 & 0.000 & 0.000 & 0.000 & 0.000 & 0.000 & 0.000 & 0.000 & 0.000 \\
$\mathrm{CB}$ & 0.013 & & 0.000 & 0.000 & 0.000 & 0.000 & 0.000 & 0.000 & 0.000 & 0.000 & 0.000 & 0.000 & 0.000 & 0.000 & 0.000 \\
$\mathrm{WB}$ & 0.030 & 0.030 & & 0.000 & 0.000 & 0.000 & 0.000 & 0.000 & 0.000 & 0.000 & 0.000 & 0.000 & 0.000 & 0.000 & 0.000 \\
$\mathrm{Ha}$ & 0.130 & 0.112 & 0.117 & & 0.000 & 0.000 & 0.000 & 0.000 & 0.000 & 0.000 & 0.000 & 0.000 & 0.000 & 0.000 & 0.000 \\
$\mathrm{Kl}$ & 0.120 & 0.101 & 0.098 & 0.050 & & 0.081 & 0.000 & 0.000 & 0.000 & 0.000 & 0.000 & 0.000 & 0.000 & 0.000 & 0.000 \\
$\mathrm{VB}$ & 0.117 & 0.093 & 0.102 & 0.042 & 0.011 & & 0.000 & 0.000 & 0.000 & 0.018 & 0.000 & 0.000 & 0.243 & 0.000 & 0.000 \\
$\mathrm{OH}$ & 0.152 & 0.111 & 0.124 & 0.049 & 0.034 & 0.021 & & 0.000 & 0.009 & 0.252 & 0.000 & 0.000 & 0.000 & 0.000 & 0.000 \\
$\mathrm{We}$ & 0.177 & 0.154 & 0.146 & 0.065 & 0.056 & 0.042 & 0.024 & & 0.324 & 0.000 & 0.000 & 0.000 & 0.000 & 0.000 & 0.000 \\
$\mathrm{Gu}$ & 0.188 & 0.160 & 0.152 & 0.083 & 0.060 & 0.057 & 0.014 & 0.003 & & 0.009 & 0.000 & 0.000 & 0.000 & 0.000 & 0.000 \\
$\mathrm{Na}$ & 0.157 & 0.121 & 0.128 & 0.080 & 0.035 & 0.020 & 0.004 & 0.029 & 0.029 & & 0.036 & 0.000 & 0.018 & 0.000 & 0.000 \\
$\mathrm{Av}$ & 0.153 & 0.122 & 0.108 & 0.102 & 0.027 & 0.021 & 0.042 & 0.061 & 0.061 & 0.018 & & 0.000 & 0.000 & 0.000 & 0.000 \\
$\mathrm{Ro}$ & 0.142 & 0.132 & 0.138 & 0.057 & 0.039 & 0.041 & 0.043 & 0.065 & 0.061 & 0.048 & 0.075 & & 0.000 & 0.000 & 0.000 \\
$\mathrm{~KB}$ & 0.113 & 0.085 & 0.095 & 0.034 & 0.021 & 0.004 & 0.028 & 0.048 & 0.067 & 0.022 & 0.037 & 0.046 & & 0.000 & 0.000 \\
Ö1 & 0.194 & 0.139 & 0.176 & 0.087 & 0.129 & 0.115 & 0.097 & 0.105 & 0.113 & 0.126 & 0.152 & 0.149 & 0.088 & & 0.216 \\
GS & 0.187 & 0.154 & 0.181 & 0.097 & 0.140 & 0.132 & 0.134 & 0.136 & 0.152 & 0.159 & 0.175 & 0.152 & 0.110 & 0.011 \\
\hline
\end{tabular}




\section{Table 3(on next page)}

Von Bertalanffy growth parameters

Von Bertalanffy growth parameters $\left(L \infty=\right.$ asymptotic length, $t_{0}=$ initial condition parameter, and $K=$ Brody growth rate or curvature parameter) and estimated mean weight at first maturity $( \pm 95 \mathrm{Cl}$ ) for lumpfish from different genetically distinct regions. 
1 Table 3. Von Bertalanffy growth parameters $\left(L \infty=\right.$ asymptotic length, $t_{0}=$ initial condition

2 parameter, and $K=$ Brody growth rate or curvature parameter) and estimated mean weight at first 3 maturity $( \pm 95 \mathrm{CI})$ for lumpfish from different genetically distinct regions.

4

\begin{tabular}{|c|c|c|c|c|}
\hline \multirow{2}{*}{ Region } & \multicolumn{3}{|c|}{ Von Bertalanffy Growth parameters } & \multirow{2}{*}{$\begin{array}{c}\text { Weight at } \\
1{ }^{\text {st }} \text { maturity }(\mathrm{g})\end{array}$} \\
\hline & $L_{\infty}(\mathrm{mm})$ & $t_{0}$ & $K\left(\mathrm{yr}^{-1}\right)$ & \\
\hline Baltic Sea & $200 \pm 6$ & $0.14 \pm 0.02$ & $0.51 \pm 0.02$ & $150 \pm 12.5$ \\
\hline East Atlantic & $461 \pm 14$ & $0.36 \pm 0.23$ & $0.56 \pm 0.09$ & $2,019 \pm 265.5$ \\
\hline English Channel & $571 \pm 22$ & $-1.08 \pm 0.59$ & $0.35 \pm 0.20$ & $3,007 \pm 519.5$ \\
\hline
\end{tabular}

5 
Figure 1

Lumpfish genetic structure

Lumpfish genetic structuring according to (A) STRUCTURESELECTOR with MedMedK and

MedMeanK, $K=5$, (B) STRUCTURESELECTOR with MaxMedK and MaxMeanK, $K=6$, and (C)

TESS with $K_{\max }=10$ based on lowest mean DIC value. Each bar represents one individual with colours indicating probability of belonging to different genetically distinct groups.

A

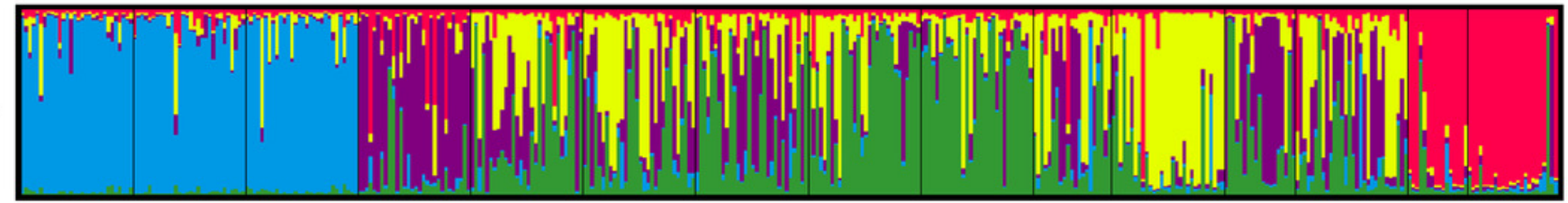

金

$\mathrm{B}$

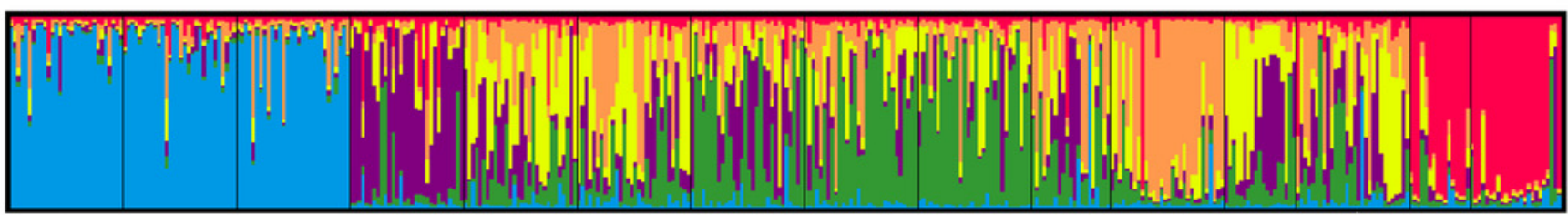

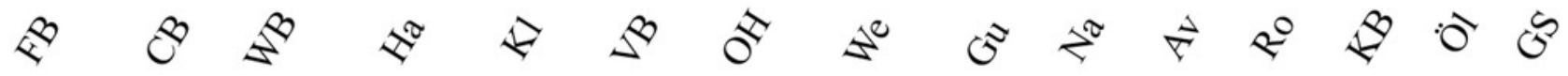

$\mathrm{C}$

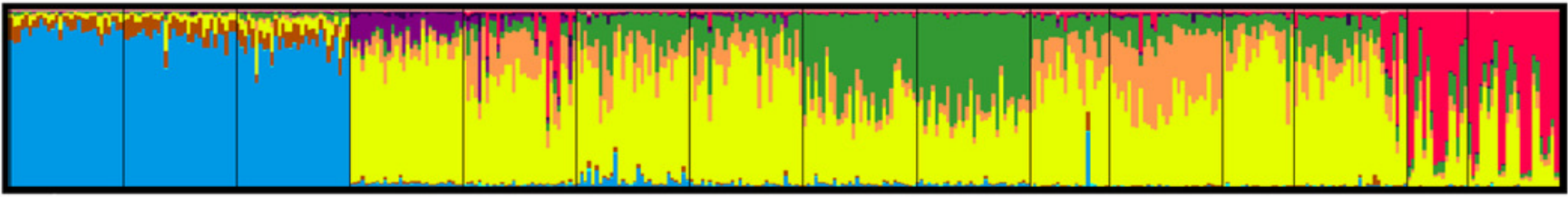

स ह 
Figure 2

Neighbourhood joining tree

Neighbour joining tree (based on Nei's Standard Genetic Distance) of 15 lumpfish populations genotyped with 10 microsatellite loci. Branch values denote $\%$ support from 1,000 bootstraps.
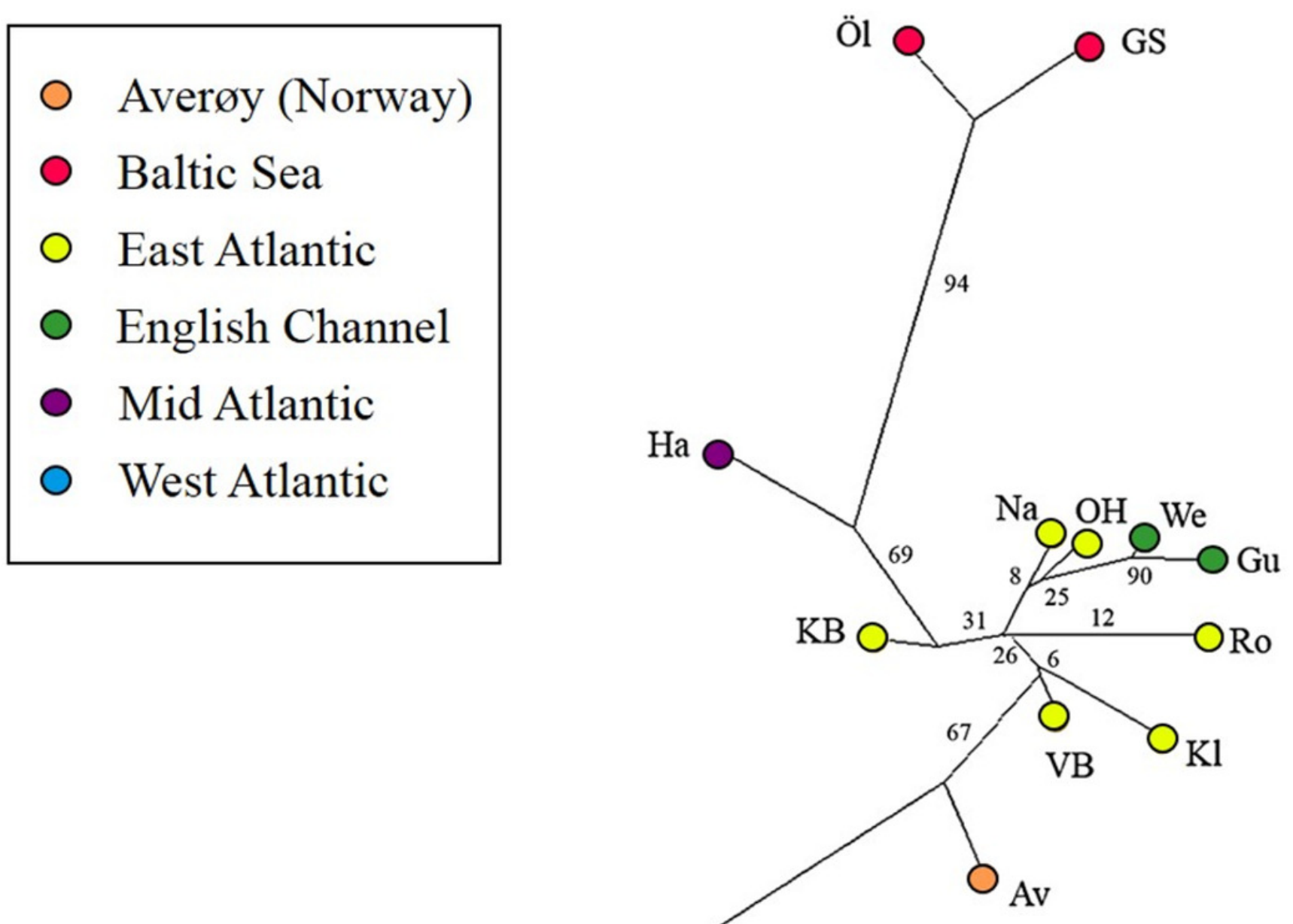

WB

\section{FB}

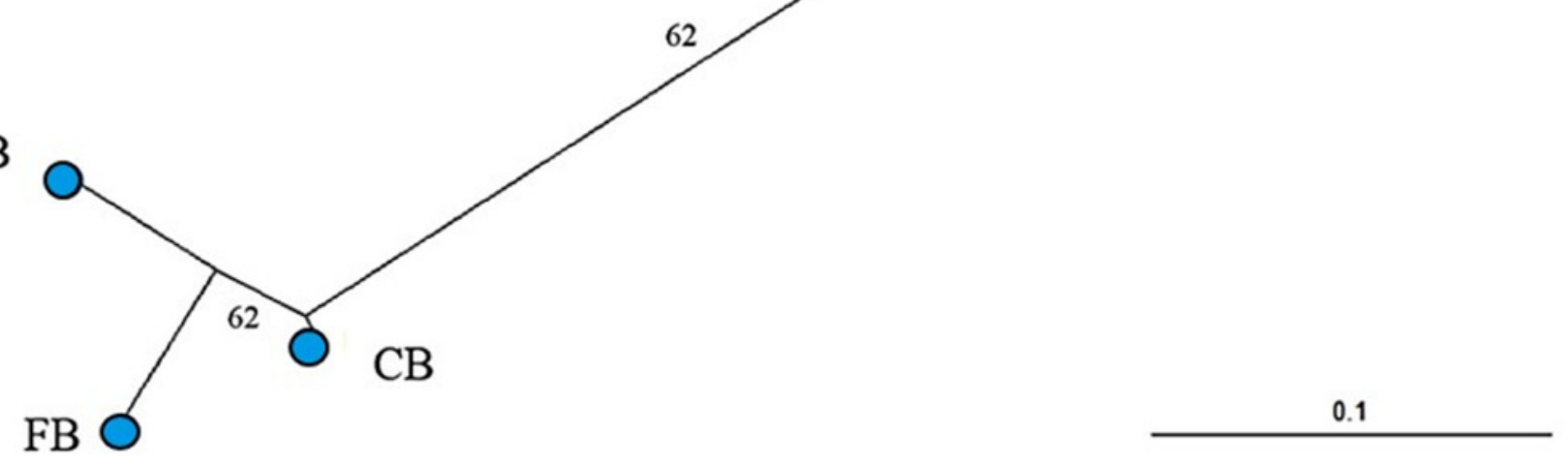


Figure 3

Patterns of gene flow among lumpfish populations with symbols indicating genetic groups, effective population size and effective number of migrants, and shaded area representing spawning distribution

Patterns of gene flow

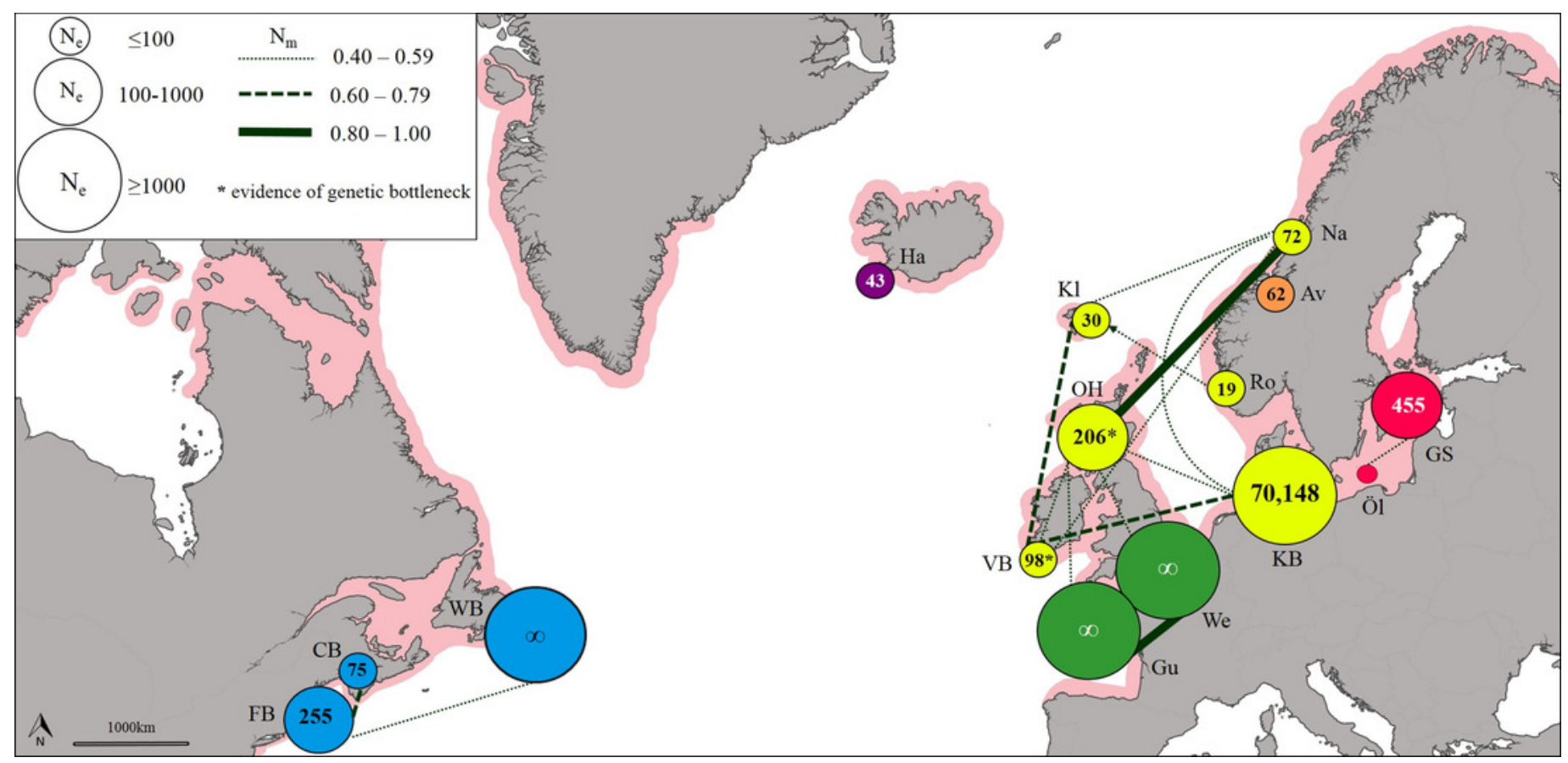




\section{Figure 4}

\section{Length-weight relationships}

Length-weight relationships ( $\log _{10}$ scale) for lumpfish sampled in the Baltic Sea, English Channel, East Atlantic and West Atlantic.

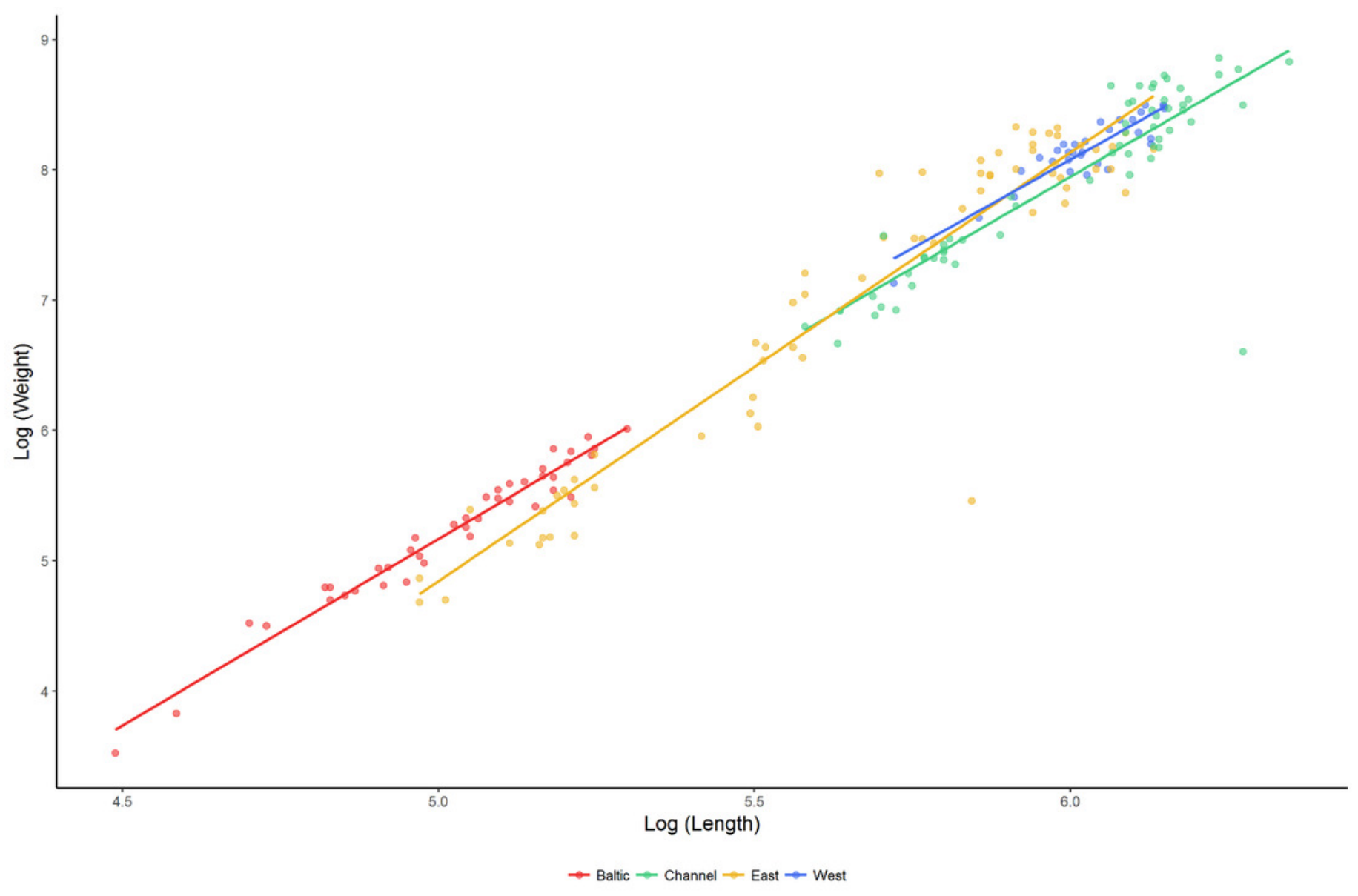

